\title{
Balkanologie
}

Balkanologie Revue d'études pluridisciplinaires

Vol. XI, n' 1-2 | 2008

Volume XI Numéro 1-2

\section{Bibliographie - Les migrations bulgares contemporaines}

\section{Nadège Ragaru}

\section{OpenEdition}

1 Journals

\section{Édition électronique}

URL : http://journals.openedition.org/balkanologie/1792

DOI : 10.4000/balkanologie. 1792

ISSN : 1965-0582

\section{Éditeur}

Association française d'études sur les Balkans (Afebalk)

\section{Référence électronique}

Nadège Ragaru, «Bibliographie - Les migrations bulgares contemporaines », Balkanologie [En ligne], Vol. XI, nº 1-2 | 2008, mis en ligne le 09 février 2009, consulté le 17 décembre 2020. URL : http:// journals.openedition.org/balkanologie/1792; DOI : https://doi.org/10.4000/balkanologie.1792

Ce document a été généré automatiquement le 17 décembre 2020.

(c) Tous droits réservés 


\title{
Bibliographie - Les migrations bulgares contemporaines
}

\author{
Nadège Ragaru
}

L'auteur souhaite remercier tous les participants à ce dossier (Aliki Angelidou, Nikolaj Gabărski, Rossitza Guentcheva, Petko Hristov, Margarita Karamihova, Mila Maeva, Elena Marušiakova, Veselin Popov, Magdalena Slavkova) ainsi que Petja Kabakčieva, Ivajlo Dičev et Anna Krăsteva pour leur aide dans la préparation de cette bibliographie.

BIBLIOGRAPHIE

\section{A - Publications en bulgare (ordre alphabétique bulgare)}

Dossier « Migrirašti kulturi » [Cultures migrantes] dirigé par Milla Mineva et Milena Jakimova, Kritika i Humanizăm [Critique et humanisme], 25, 2008, sommaire à l'adresse : http:// www.eurozine.com/journals/critiquehumanism/issue/2008-04-23.html

Hristo Angelov, Priobštavane na kvalificiranata emigracija kăm Bălgarija [Attirer l'émigration qualifiée en Bulgarie], Sofia : Agence pour les Bulgares de l'étranger, à l'adresse :

http://www.aba.government.bg/bg/pages/Izsledvaniya/Reintegration/NovaBG.html Svetlana Antova, 'Tuk živeem, tykašem hljab jadem'. Etnokulturna identičnost na bălgarite v Slovakija ['Nous vivons ici, c'est le pain d'ici que nous mangeons'. L'identité ethnoculturelle des Bulgares en Slovaquie], Sofia : Paradigma, 2007. 
Atanas Atanasov, Praktikite na njakoi evropeiski strani za reintegracija na visokokvalificirani specialisti [Les pratiques de quelques pays européens en matière de réintégration des spécialistes hautement qualifiés], Sofia : Agence pour les Bulgares de l'étranger, à l'adresse : http:// www.aba.government.bg/bg/pages/Izsledvaniya/Reintegration/BAN.html

I. Baeva, « Bălgari v nedalečnata čužbina » [Bulgares dans un étranger proche], in : Bălgarija $i$ iztočna evropa [La Bulgarie et l'Europe de l'Est], Sofia : Paradigma, 2001.

Ivan Balev, « Meždunarodnata migracija i problemi pri nejnoto statističesko nabljudenie v Bălgarija » [Migrations internationales et problèmes relatifs à son observation statistique en Bulgarie]. A report presented at a conference on migration organised by the Open Society Institute (OSI), Sofia: OSI, October 2004.

BBSS - Gallup Bulgaria, « Evropejskijat proekt na Bălgarija : emigracijata kato diagnoza » [Le projet européen en Bulgarie : l'émigration comme diagnostic], Foreign Policy - Bulgaria, 4, avril-mai 2005, p.88.

Daniela Bobeva, Ivan Čalăkov i Jordan Markov, Migracijata - evropejskata integracija i iztičaneto na mozăci ot Bălgarija [La migration : l'intégration européenne et la fuite des cerveaux en Bulgarie], Sofia : Center for the study of Democracy (CSD), 1996, à l'adresse : http://www.csd.bg/ artShowbg.php?id=6823

Georgi Vasilev, « Văzmožnijat koridor na zavrăštane - formi i varianti » [Corridor possible pour un retour. Formes et variantes]. Paper presented at the international conference « Attraction of young scholars - strategies against brain-drain », organised by the Bulgarian Ministry of Education and the German DAAD and HRK on 18-20 October 2002, à l'adresse: http:// www.aba.government.bg/bg/pages/Izsledvaniya/Research/index-r.htm

Bojka Vasileva, Bălgarskata političeska emigracija sled Vtorata svetovna vojna [L'émigration politique bulgare après la seconde Guerre mondiale], Sofia : Universitetsko Izdatelstvo « Sveti Kliment Ohridski », 1999.

Bojka Vasileva, Migracionnite procesi v Bălgarija sled Vtorata svetovna vojna [Les processus migratoires en Bulgarie après la seconde Guerre mondiale], Sofia : n.d., 1992.

Todor Galev, Ivan Čalăkov, « Naglasi za emigracija sred studentite ot informacionni i komunikacionni tehnologii v Bălgarija » [Attitudes en faveur de l'émigration parmi les étudiants bulgares en information et en technologies de la communication], Nauka (Science), 6, 2006, p.

21-27.

Rossitza Guentcheva, « Pătuvaštite bălgari po vremeto na socialisma » [Les Bulgares voyageurs sous le socialisme], Foreign Policy-Bulgaria, 4, avril-mai 2005, p.34-37.

Rossitza Guentcheva, « Obrazite na Zapada v Bălgarskite pătepisi ot vreme na socialisma (1944-1989) [Les images de l'Occident dans la littérature de voyage à l'époque du socialisme (1944-1989)], in : Magdalena Elčinova (dir.), Antropologični izsledvanija [Etudes anthropologiques], Sofia : Nov Bălgarski universitet, vol. 6, 2006, p.93-107.

Rossitza Guentcheva, « Recensija na Figurite na bežaneca, săstavitel i naučna redakcija Anna Krăsteva (Poredica Migracionni i bežanski izsledvanija, Izdatelstvo na Nov Bălgarski Universitet : Sofia, 2006] » [Recension des Figures du réfugié, sous la direction de Anna Krăsteva], in : Godišnik na Departamenta po Antropologija na NBU, 2007.

Rossitza Guentcheva, « Kak da mislim postsocialističeskata vătrešna migracija v Bălgarija (1989-2006 » [Comment penser les migrations internes en Bulgarie (1989-2006)], Antropologičeski izsledvanija [Etudes anthropologiques], Sofia : Nov Bălgarski Universtitet, volume 7 (à paraître). 
Kostadin Gărdev, Bălgarskite obštnosti v Čehija i Slovakija : minalo i nastojašte [Les communautés bulgares en Tchéquie et en Slovaquie : passé et présent], Sofia : UI «Sveti Kliment Ohridski », 2003.

Kostadin Gărdev, Bălgarskata emigracija v Kanada [L'émigration bulgare au Canada], Sofia : UI «Sveti Kliment Ohridski », 1998.

Simeon Damjanov, Ljuben Berov, Bălgarite v Avstralija [Les Bulgares en Australie], Sofia : BAN, 1986.

Neda Deneva, « Meždunarodna i vătrešna migracija v edno bulgaro-mjusulmansko selo : priliki i razliki pri mobilizacjata na mreži » [Migrations internationales et internes dans une village bulgare-musulman : similitudes et différences dans la mobilisation des réseaux »], in : Ralitsa Soultanova (dir.), Kartini ot bălgarskite migracii sled 1989 [Images des migrations bulgares après 1989], Sofia : IVREY, 2008 (à paraître).

Emil Dimitrov, « Geografski osobenosti i analiz na ežednevnite trudovi migracii v Bălgarija » [Particularités géographiques et analyse des migrations de travail quotidiennes en Bulgarie], Naselenie (Population) 6, 1992, p.22-33.

Vetka Žekova, « Vătrešna i vănšna migracija na naselenieto v Bălgarija » [Migrations internes et internationales de la population en Bulgarie], Ikonomičeski izsledvanija (Etudes économiques), 2, 2006, p.175-204.

Jordan Kalčev, Vănšnata migracija na naselenieto v Bălgarija [Les migrations internationales de la population en Bulgarie], Ruse : Dunav Press, 2001.

Jordan Kalčev, Vătresnata i văšnna migracija na naselenieto prez 90-te godini [Les migrations internes et internationales de la population dans les années 1990], Sofia : Nacionalen statističeski institut (NSI), 1992.

Jordan Kalčev et Sergej Cvetarski, Potencialnata emigracija na pătuvaštite v čužbina bulgarski graždani [L'émigration potentielle des citoyens bulgares voyageant à l'étranger], Sofia : Nacionalen statističeski institut (NSI), vol. 2, 1993.

Jordan Kalčev et Sergej Cvetarski, Potencialnata emigracija na pătuvaštite v čužbina bulgarski graždani [L'émigration potentielle des citoyens bulgares voyageant à l'étranger], Sofia : Nacionalen statističeski institut (NSI), Vol.1, 1991.

Margarita Karamihova, « Dviženija v planinskija sviat prez pogleda na nepodvižnite » [Les mouvements dans le monde montagnard à travers le regard de ceux qui ne se déplacent pas], Iztok-Iztok (Est-Est), 18-19, 1995, p.46-50.

Margarita Karamihova, « Edno văzmožno malcinstvo (sondažno izsledvane na obštnostta na bălgarite-imigranti v Sejnt Pijtsbărg, Florida » [Une minorité potentielle. Etude par sondage de la communauté des Bulgares immigrants à Saint Pittsburgh, Florida], Istoričesko bădešte (Futur historique), 2, 2001, p.194-217.

Margarita Karamihova, «Pieneto kato etno-marker za bălgarite-emigrante v SAŠT » [Boire comme ethno-marqueur pour les Bulgares émigrants aux Etats-Unis], MIF Vino i Kultura (Vin et culture), 8, 2003, p.212-240.

Margarita Karamihova, « Funkcii na semejstvoto pri părva generacija imigranti v SAŠT » [Les fonctions de la famille dans la première génération d'immigrants aux Etats-Unis], Antopologični izsledavanija (Etudes anthropologiques), 4, 2003, p.131-158.

Margarita Karamihova, « Trakiecăt ot « novijat svjat » [Le Thrace du 'Nouveau monde'], in : Trakiecăt i negovijat svjat. Dokladi ot tretata naučna etnografska konferencija [Le Thrace et son monde. 
Rapports de la troisième conférence universitaire ethnographique], Sofia : EIM, 2004, volume 2, p. 303-326.

Margarita Karamihova, «Ežednevieto na emigranta » [Le quotidien de l'émigrant], in : Vsekidnevnata kultura na bălgarite i sărbite v postsocialističeskijat period. Treta bălgaro-srăbska naučna konferencija [La culture quotidienne des Bulgares et des Serbes dans la période post-socialiste. Troisième conférencence universitaire bulgaro-serbe], Sofia : EIM-BAN, 2005, p.224-230.

Margarita Karamihova (dir.), Gradivo za etnologija na migraciite [Contribution à l'étude des migrations], Sofia : EIM-BAN, 2006.

Margarita Karamihova, Amerikanski mečti. Pătevoditel sred părva generacija imigranti [Les rêves américains. Guide chez les immigrants de première génération], Sofia : IK 'Krotal', 2004.

Margarita Karamihova (dir.), Da živeeš tam, da se sănuvaš tuk. Emigracionni procesi v načaloto na XXI vek, [Vivre là-bas, se rêver ici. Processus migratoires au début du XXIème siècle], Sofia : IMIR, 2003.

Margarita Karamihova, « Emigracijata ot Rodopite - Nov fenomen ili vremenen otgovor v perioda na kriza » [L'émigration depuis les Rhodopes. Phénomène nouveau ou réponse temporaire en période de crise ?], in : Margarita Karamihova (dir.), Da živeeš tam, da se sănuvaš tuk. Emigracionni procesi v načaloto na XXI vek, [Vivre là-bas, se rêver ici. Processus migratoires au début du XXIème siècle], Sofia : IMIR, 2003, p.23-108.

Anna Krăsteva (dir.), Da bădeš čuždenka v Bălgarija [Etre étrangère en Bulgarie], Sofia : n.d., 2009 (à paraître).

Anna Krăsteva (dir.), Figurite na bežaneca [Les figures du réfugié], Sofia : Nov Bălgarski Universitet, 2006.

Anna Krăsteva (dir.), Imigracijata v Bălgarija [L'immigration en Bulgarie], Sofia : IMIR, 2005.

Anna Krăsteva (dir.), Ot etničnost kăm migracija [De l'ethnicité aux migrations], Sofia : Nov Bălgarski Universitet, 2004.

Marina Liakova, « Hibridnijat žiznen svjat na bălgarskite studenti v Germanija » [L'univers hybride des étudiants bulgares en Allemagne], Kritika i Humanizăm (Critique et humanisme), 25, 2008, p.45-63.

Mila Maeva, « Săvremenni migracionni vălni na bălgarskite turci » [Nouvelles vagues de migrations contemporaire des Turcs bulgares], in : Mirella Dečeva (dir.), Dinamika na nacionalnite $i$ transnacionalnite identičnosti $v$ procesa na evropejskata integracija [Dynamiques des identités nationales et transnationales dans le processus d'intégration européenne], Sofia : Paradigma, 2008, p.333-356.

Mila Maeva, Bălgarskite turci-preselnici v Republika Turcija (kultura i identičnost) [Les Turcs bulgares installés en République de Turquie (culture et identité)], Sofia : IMIR, 2006.

Mila Maeva, «Religija i identičnost na turcite, preselnici ot Bălgarija v Republika Turcija » [Religion et identité des Turcs ayant émigré depuis la Bulgarie vers la République de Turquie], in : Margarita Karamihova (dir.), Ti imaš ajsen znak! 'Zavrăštane' na religiosnostta v kraja na XX i načaloto na XXI vek [Tu as un signe distinctif clair ! Le « retour » de la religiosité à la fin du XXème et au début du XXIème siècle], Sofia : Faber OOD, 2007, p.143-158

Mila Maeva, « Emigracija na turci ot Bălgarija kăm ES » [L'émigration des Turcs depuis la Bulgarie vers l'Union européenne], in : Čelovek $v$ istorii i kuljture [L'homme dans l'histoire et la culture], Odessa-Ternovka : Druk, 2007, p.376-385. 
Mila Maeva, « obredna trapeza i identičnost na bălgarskite turci-preselnici v Republika Turcija » [La table rituelle et l'identité des Turcs bulgares en Turquie], in : Obrednata trapeza. Sbornik dokladi ot XI-ta Nacionalna konferencija na bălgarskite etnografi - Plovdiv, 2005 [La table rituelle. Actes de la Conférence nationale des ethnographes bulgares, Plovdiv, 2005], Sofia : n.d., 2006, p.344-351.

Mila Maeva, « Ezik i etnokulturana identičnost na bălgarskite turci v R Turcija » [Langue et identité ethnoculturelle chez les Turcs bulgares en République de Turquie], Bălgarska etnologija (Ethnologie bulgare, Ethnologia Bulgarica), 2, 2004, p.59-74.

Mila Maeva, « Obrazăt na turcite v R Turcija prez pogleda na bălgarskite turci-preselnici » [L'image des Turcs de République de Turquie dans le regard des migrants turcs bulgares], Bălgarska etnologija (Ethnologie bulgare), 4, 2002, p.42-55.

Mila Mančeva, « Trudova migracija na bălgarskite turci v Germanija. Săetnički mreži i kulturi » [La migration de travail des Turcs bulgares en Allemagne. Réseaux et cultures migrants coethniques], Kritika i Humanizăm (Critique et humanisme), 25, 2008, p.25-44.

Elena Marušiakova et Veselin Popov, Studii Romani. Izbrano [Etudes tsiganes. Textes choisis]. Sofia : Paradigma, vol. 7, 2007.

Elena Marušiakova et Veselin Popov, « Dălgijat i kăsijat păt do Odesa (Migracijata na dve ciganski grupi)» [Le chemin long et court jusqu'à Odessa (Migration de deux groupes tsiganes)], in : Margarita Karamihova (dir.), Gradivo za etnologija na migraciite [Contribution à l'étude des migrations], Sofia : EIM-BAN, 2006, p.7-30.

Ognian Mintchev, « Meštata/košmarat Evropa » [Rêve/cauchemar Europe], Foreign Policy Bulgaria, avril-mai 2005, p.40-41.

Vesselin Mintchev, « Empirični ocenki za naglasite na zavărnalite se bălgarski emigranti [Evaluations empiriques des attitudes des migrants bulgares rentrés (en Bulgarie)], Ikonomičeska misăl (Pensée économique), 5, 2007, p.13-32.

Vesselin Mintchev, «Bălgarskata emigracija v načaloto na XXI vek : ocenka na naglasite i profila na potencialnite emigranti » [L'émigration bulgare au début du XXIè siècle : évaluation des attitudes et profil des migrants potentiels], Ikonomičeska misăl (Pensée économique), 5, 2004, p. 3-30.

Vesselin Mintchev, « Ikonomikata na bălgarskata emigracija - empirični ocenki » [L'économie des migrations bulgares : évaluations empiriques], Ikonomičeska misăl (Pensée économique), 2, 2006, p.23-47.

Nikolaj Mišev, Emil Dimitrov, « Văzratni trudovi migracii v Bălgarija - razvitie, ocenka i problemi » [Migrations du travail réversibles en Bulgarie. Développement, évaluation et problèmes], Naselenie (Population), 7(2), 1989, p.54-69.

Penka Najdenova, « Istoričeski i săvremenni problemi na bălgarskata emigracija v Amerika » [Problèmes historiques et contemporaines de l'émigration bulgare en Amérique], Naselenie (Population), 4, 1993, p.97-100.

Veselin Popov, « Cigani v Krim » [Roms en Crimée], in : Veselin Popov, Rossitza Genčeva (eds.) Etnografski etjudi. Sbornik po povod 70-godišninata ot roždenieto na prof. d.i.n. Stojan Genčev (1936-1990) [Etudes ethnographiques. Volume à l'occasion du 70ème anniversaire de la naissance $d u$ professeur Stojan Genčev] ; Sofia : EIM-BAN, 2006, p.308-325.

Natalja Raškova, Vladimir Penčev, Bălgari v Slovakija. Etnokulturni harakteristiki i vzaimodejstvija [Bulgares en Slovaquie. Caractéristiques ethnoculturelles et interactions], Sofia : BAN, 2006. 
Stefan Simeonov, « Istoriko-pravni aspekti na bežanskija văpros v Bălgarija » [Aspects historiques et juridiques de la question des réfugiés en Bulgarie], Bjuletin 'Fakultet policija', 9, 2001, p.93-104.

Magdalena Slavkova, « Săvremenni trudovi migracii na bălgarski cigani kăm Ispanija i tiahnoto otraženie vărhu identičnostta im » [Les migrations de travail contemporaines des Roms bulgares à destination de l'Espagne et leurs répercussions sur leur identité], in : Mirella Dečeva (dir.), Dinamika na nacionalnata identičnost $i$ transnacionalnite identičnosti $v$ procesa na evropeiska integracija [Dynamique de l'identité nationale et des identités transnationales dans le processus d'intégration européenne], Sofia : Paradigma, 2008.

Bonka Stojanova-Boneva, Amerikanci po bălgarski ili bălgari po amerikanski [Américains à la bulgare ou Bulgares à l'américaine], Sofia : UI « Sveti Kliment Ohridski », 1991.

Ilona Tomova, « Vănšni migracii pri romite v postkomunističeska Bălgarija : pričini, naglasi, povedenie i posledici » [Les migrations internationales des Roms en Bulgarie post-communiste : causes, attitudes, comportements et conséquences], Sociologičeski problemi (Problèmes sociologiques), 41, 2008, p.154-177.

Veselin Trajkov, Istorija na bălgarskata emigracija v Severna Amerika [Histoire de l'émigration bulgare en Amérique du nord], Sofia : UI « Sveti Kliment Ohridski », 1993.

Evgenja Troeva et Valeri Grigorov, « Gurbečijstvoto v Rodopite, minalo i nastojašte » [Le gurbet dans les Rhodopes. Passé et présent], in : Da živeeš tam, da se sănuvaš tuk. Emigracionni procesi v načaloto na XXI vek, [Vivre là-bas, se rêver ici. Processus migratoires au début du XXIème siècle], Sofia : IMIR, 2003, p.109-123.

Petko Hristov, « Gurbetčijstvoto/pečalbarstvoto v centralnata čast na Balkanite kato transgraničen obmen » [Le gurbet et le pečalbarstvo dans la partie centrale des Balkans comme échange transfrontalier], Balkanističen forum (Forum balkanistique, Blagoevgrad), 1-2-3, 2004, p. 48-54.

Petko Hristov, « Granicite na 'Šopluka' i/ili šopi bez granici » [Les frontières du Šopluk et/ou les Šops sans frontières], in : Skrivene manjine na Balkanu [Les minorités cachées dans les Balkans], Belgrade : Institute for Balkan Studies, 2004, p.67-82.

Petko Hristov, « 'Vlaško' kato važna destinacija za sezonnite rabotnici (pečalbari) ot centralnata čast na Balkanite » [La Valachie comme destination importante des migrants saisonniers (pečalbari) de la partie centrale des Balkans], Probleme de filologie slava (Problèmes de philologie slave, Timisoara), 15, 2007, p.465-473.

Evgenja Cekova, «Zagubite na naučen potencial ot zvenata na BAN prez 1990-1992 » [La perte de potentiel universitaire depuis BAN en 1990-1992], Naselenie (Population), 4, 1993, p.93-96.

Valentina Šarlanova, « Pogled vărhu procesite na integracija i konstruirane na identičnost na junoši ot imigranski proizhod v obštestvo priemnik » [Regard sur les processus d'intégration et de construction de l'identité chez les jeunes d'origine immigrée dans la société d'accueil], Bălgarska etnologija (Ethnologie bulgare, Ethnologia bulgarica), 1, 2005, p.48-65.

\section{B - Publications dans d'autres langues}

Ali Ahmad, « The Labour Market Consequences of Human Smuggling : 'Illegal Employment in London's Migrant Economy ", Journal of Ethnic \& Migration Studies, 34(6), août 2008, p.853-874. 
Aliki Angelidou, «Becoming the breadwinners : Economic practices and gender identities among Bulgarian female migrants in Athens ", To Vima ton Koinonikon Epistimon [La tribune des sciences sociales], 2008, 18p. (à paraître).

Svetlana Antova, « The Bulgarian Ethnic Community in Slovakia. An Attempted Chronological and Typological Analysis », Etnologia Bulgarica, 3, 2006, p.93-102.

William Bagatelas, Bruno Sergi, « The Balkans 'brain drain' - its meaning and implications », South-East Europe Review for Labour and Social Affairs, 4, 2003, p.7-12.

Martin Baldwin-Edwards, « Patterns of Migration in the Balkans », UEHR Working Papers (Athens), 9, 2006, à l'adresse : http://www.mmo.gr/pdf/publications/mmo_working_papers/ mmo_wp9.pdf

Martin Baldwin-Edwards, « Sustainable Development and Emigration : The Contemporary Balkans and the European Union », South East Europe Review for Labour and Social Affairs, 7 (1), 2004, à l'adresse : http://www.ceeol.com/aspx/getdocument.aspx?logid=5\&id=8C18BCEB-B9CA-4A0EA620-D4ACB39D39C5

Mathias Beer (Hg.), Migration nach Ost- und Südosteeuropa vom 18. bis zum Beginn des 19. Jahrhunderts : Ursachen - Formen - Verlauf-Ergebnis, Stuttgart : Thorbecke, 1999.

Daniela Bobeva, Migration. Europe's Integration and the Brain Drain from Bulgaria, Sofia : Center for the Study of Democray (CSD), 1996, à l'adresse : http://www.csd.bg/fileSrc.php?id=10685

Daniela Bobeva, « Emigration from and Immigration to Bulgaria », in : Heinz Fassmann and Rainer Münz (eds.), European Migration in the Late Twentieth Century. Historical Patterns, Actual Trends, and Social Implications, Aldershot : Edward Elgar, 1994, p.221-37.

Daniela Bobeva, Emigration of Scientists and Engineers from Bulgaria, Sofia, 1993, à l'adresse : http:// www2.online.bg/econ/policy/emigr/main.htm

Ulf Brunnbauer, « Environment, Markets and the State : Human Adaptation in the Balkan Mountains, 19th - early 20th Century », Ethnologia Balkanica, 8, 2004, p. 129-154.

Bulgarian Helsinki Comittee, Research on the Rights of Migrants in Bulgaria from a Human Rights Perspective, Sofia : BHC, November 2006, à l'adresse : http://www.bghelsinki.org/ index.php?module=resources\&lg=en\&id=0\&cat_id=18 - 2006

Ayse Caglar, « Home Town Associations, the Rescaling of State Spatiality and Migrant Grassroots Transnationalism », Global Networks 6(1) 2006, p.1-22.

Mario Cervantes and Dominique Guellec, « The Brain Drain : Old Myths, New Realities », OECD Observer, 7 May 2002, à l'adresse : http://www.oecdobserver.org/news/fullstory.php/aid/673/ The_brain_drain:_old_myths,_new_realities.html

Ivan Chompalov, Brain Drain from Bulgaria Before and After the Transition to Democracy. Paper prepared for the Bulgarian Research Symposium and Network Meeting in Atlanta, GA, April 7, 2000, à l'adresse : http://www.cherry.gatech.edu/bg/sym/proceed/chompolov.PDF

Neda Deneva, « On the Margins of Two States : Flexible Self-identification Strategies of Bulgarian Muslims in Spain », 2008, à l'adresse : http://www.migrationonline.cz/e-library/?x=2090875

Neda Deneva, « Migration on the Margins of the State(s) : Bulgarian Muslims betwixt and between Bulgaria and Spain ». Actes du colloque « New Migration Dynamics : Regular and Irregular Activities on the European Labour Market », 7-8 décembre 2007, Nice, p.71-98, à l'adresse : http://www.unice.fr/migractivities/05_EnjeuxOrigine.pdf 
Neda Deneva, « The Role of Ethnicity in the Re-construction of the Community: Internal and International Migration in a Bulgarian Muslim Village », in : Alice Szczepanikova, Marek Canek and Jan Grill (eds.), Migration Processes in Central and Eastern Europe. Unpacking the Diversity, Prague : Multikulturní centrum Praha/Multicultural Center Prague, 2006, à l'adresse : http:// www.migration-boell.de/downloads/integration/Migration_Processes_in_CEE_MKC.pdf

Donka Dimitrova, « Bulgarian Turkish Immigrants of 1989 in the Republic of Turkey. Adaptation and Changes in the Cultural Model ", in : A. Zhelyazkova (ed.), Between Adaptation and Nostalgia. The Bulgarian Turks in Turkey, Sofia : International Center for Minority Research and Intercultural Relations (IMIR), 1998, p.76-139.

Ivaylo Ditchev, «Crossing borders », Eurozine, août 2008, à l'adresse : http://www.eurozine.com/ articles/2006-08-31-ditchev-en.html

Ivaylo Ditchev, « Mobility and Citizenship. The Soft Borders within the EU », in : Krassimir Nikolov (dir.), Adapting to integration in an enlarged European union, Sofia : Bulgarian European Communities Studies Association (ECSA), 2008, vol. 2, p.243-263.

Ivaylo Ditchev, « Identités mobiles? Citoyenneté mobile? » [Mobilni identičnosti ? Mobilno Graždanstvo ? », Kritika i Humanizăm, 25, 2008, à l'adresse : http://www.eurozine.com/articles/ 2008-06-27-ditchev-bg.html

Ivaylo Ditchev, « The Danube frontier », in : Andreas Mueller-Pohle (ed.), The Danube project, Berlin : Peperoni books, 2007, p.9-20.

Ivaylo Ditchev, « Le citoyen mobile et l'ombre de son identité », in : Michel Rautenberg (dir.), La Bulgarie et l'Europe, Paris : L'Harmattan, 2007, p.165-178.

Ivaylo Ditchev, « Metamorphoses of Territory », Journal of Contemporary European Studies, 14 (2), 2006, p.213-220.

Ivaylo Ditchev, « Fluid citizenship? Utopia of freedom or reality of submission », Eurozine, février 2006, http://www.eurozine.com/articles/2006-02-15-ditchev-en.html Published 2006-02-15, (originellement publié en anglais dans Transit)

Ivaylo Ditchev, « Communist Urbanization and Conditional Citizenship », City, 9 (3), déc. 2005, p. 341-354.

Ali Eminov, Turkish and Other Muslim Minorities, London : Hurst \& Co., 1997.

Kjell Engelbrekt, « Bulgaria and the Problem of Immigration », RFE/RL Research Report, 25 (3), 1994, p.37-40.

Birsen Ersel, « The Social and Political Problems Raised by the Emigration of Turkish Workers », South-East Europe Review for Labour and Social Affairs, 04/2001, p.37-50.

European Action Citizen Service (ECAS), Who's Afraid of the EU's Latest Enlargement? The Impact of Bulgaria and Romania joining the Union on Free Movement of Persons, ECAS, 2008.

Angus M. Fraser, « The Rom Migrations », Journal of the Gypsy Lore Society, 5(2), 1992, p.131-145.

Rossitza Guentcheva, « Images of the West in Bulgarian Travel Writing during Socialism (1945-1989) ", in : Wendy Bracewell and Alex Drace-Francis (eds), Under Eastern Eyes : A Comparative Introduction to East European Travel Writing on Europe, Budapest \& New York : Central European University Press, 2008, p. 355-378.

Rossitza Guentcheva, « From Banishment to Ascribed Residence: Controlling Internal Movement in Socialist Bulgaria (1944-1989) ». Paper in the framework of the project « Roles, Identities and 
Hybrids » of the Centre for Advanced Study - Sofia, May 2006, à l'adresse : http://v3.cas.bg/ cyeds/downloads/From_Banishment_to_Ascribed_Residence.pdf

Magdaléna Hadjiisky, «L'émigration des intellectuels bulgares : entre l'exode et le retrait du politique », L'Autre Europe, 30-31, 1995, p.76-92.

Guy H. Haskell, From Sofia to Jaffa : The Jews of Bulgaria and Israel, Detroit, Mich.: Wayne State University Press, 1994.

Panos Hatziprokopiou, « Migration and Changing Urban Geographies in the European South : Evidence from the Case of Immigrants in Thessaloniki », Migration and Ethnic Themes, (1-2), 2006, p.113-136.

Wolfgang Höpken, « Emigration und Integration von Bulgarien-Türken seit dem Zeiten Weltkrieg. Ein Vergleich der Auswanderungswellen von 1950/51 und 1989 » [Emigration et intégration des Turcs bulgares depuis la seconde Guerre mondiale. Une comparaison des expulsions de 1950/1951 et de 1989]. In : Gerhard Seewann (dir.), Minderheitfragen in Südosteuropa [Les questions de minorités en Europe du Sud-Est], Munich : Oldenbourg Verlag, 1992, p.359-375. Petko Hristov, « Trans-border Exchange of Seasonal Workers in the Central Part of the Balkans », Ethnologia Balkanica, 12, 2008 (à paraître).

Petko Hristov, « Wherever I go, I would return home...» : Pechalbars' Routes on the Balkans », Macedonian folklore (Skopje), 65, 2008, p.115-122.

Petko Hristov, « Celebrating the Abandoned Village (pusto selo): Pictures from the Ritual Process in the Post-Socialist Balkans ", In : Biljana Sikimić and Petko Hristov (eds.), The Kurban on the Balkans, Belgrade : Institute for Balkan Studies, 2007, p.245-258.

Petko Hristov, «A Comparative Study of the Border Areas in the Balkans. Problems and Perspectives », Symposia (Craiova), 3, 2006, p.77-84.

Petko Hristov, « Places to Exchange Cultural Patterns : The Market and the Piazza for Hired Labour in Sofia », Ethnologia Balkanica, 9, 2005, p.81-90.

Ivan Ilchev, « Emigration and the Politics of Identity », in : Jonathan Stein (ed.), The Politics of National Minority Participation in Post-Communist Europe : Statebuilding, Democracy and Ethnic Mobilization, Armonk, NY : East-West Institute, 2000, p.237-268.

Institute for Public Policy Research (IPPR), Bulgaria and Romania - Migrations Implication for the UK, EU Enlargement FactFile, avril 2006, à l'adresse : http://www.ippr.org/members/ download.asp?f=/ecomm/files/eu_enlargement_factfile.pdf\&a=skip

Elena Jileva, « Insiders and outsiders in Central and Eastern Europe : The case of Bulgaria », in : Kees Groenendijk, Elspeth Guild and Paul Minderhoud (eds.), Search of Europe's Borders, The Hague : Kluwer Law International, 2002, p.273-87.

Petya Kabakchieva, « Crossing Borders : Changing Roles, Changing Identities (Temporary Migration as a Form of Socio-Cultual Exchange in the Enlarged EU) », Research Paper, Sofia : Center for Advanced Studies (CAS), 2006, à l'adresse: http://v3.cas.bg/cyeds/downloads/ CAS_RIH_Kabakchieva.pdf

Petya Kabakchieva, « Temporary Migrants : Beyond Roles, Across Identities », in : Aleksander Kiossev and Petya Kabachieva (eds.), Rules and Roles: Fluid Institutions, Hybrid Roles and Identities in East European Transformation Processes (1989 - 2005), Freiburg : LitVerlag, à paraître. 
Jordan Kalchev, Vesselin Mintchev, S. Blajeva, Rossitsa Rangelova, Venelin Boshnakov, K. Vladimirova, « Gender Dimension of the Bulgaria's New Migration : Policy Implications », Ikonomičeski izsledvanija (Etudes économiques), 1, 2006, p.43-66.

Iordan Kalchev, « Migrations internes et internationales de la population de Bulgarie au cours de la deuxieme moitie du XX-eme siecle », in : La démographie des Balkans, Thessalonique : n.d., 1996.

Margarita Karamihova, «Identities Palette in the Course of European Integration. A Case Study of Satovcha Village », in : Elena Marushiakova (ed.), Dynamics of National Identity and Transnational Identities in the Process of European Integration, Cambridge : Cambridge Scholars Publishers, 2008, p. 248-270.

Margarita Karamihova, « C'est un signe du destin!. La dynamique des rapports entre un groupe d'émigrés et leur pays natal », in : Vivre ensemble au XXème siècle. Actes du colloque international de l'Institut de sociologie, Bruxelles : Université libre de Bruxelles, 2007, p.427-446.

Anelia Kassabova-Dincheva, Migration und Familie. Familienforschung und Politik (am Beispiel Bulgariens), Sofia : IK Variant 2000, 2002.

Kemal Kirişçi, « Refugees of Turkish Origin : Coerced Immigrants to Turkey Since 1945 », International Migration, 34(3), 1996, p.385-412.

Yulian Konstantinov, « Patterns of Reinterpretation : Trader-Tourism in the Balkans (Bulgaria) as a Picaresque Metaphorical Enactment of Post-totalitarianism », American Ethnologist 23(4), 1996, p.762-782.

Yulian Konstantinov, « Small-scale trading in Bulgaria in the context of post-totalitarian changes - an introduction to trader-tourism ", In : Yulian Konstantinov, Gideon Kressel and Trond Thuen (eds.), Working Papers on Trader-Tourism, Sofia/Sede Boquer/Tromsø, 1996, vol. 1, p.1-7.

Yulian Konstantinov and Trond Thuen, « Boundaries as a Resource: Regional Small-Scale Trading in the Balkans ", Occasional Papers (Stensilserie), 84, 1996, Institute of Social Science, University of Tromsø.

Yulian Konstantinov, « Hunting for Gaps Through Boundaries : Gypsy Tactics for Economic Survival in the Context of the Second Phase of Post-totalitarian Changes in Bulgaria ", European Journal of Social Sciences, 7(3), 1994, p.237-248.

Svetla Kostadinova, « Bulgarian Emigrants - More Benefits than Losses for Bulgaria », Sofia : Institute for Market Economy (IME), 2005, à l'adresse :

http://ime.bg/uploads/docs/5f4c0b_Migration_Svetla.pdf

Petăr Krastev, « Understated, Overexposed. Turks in Bulgaria-Immigrants in Turkey », in : A. Zhelyazkova (ed.), Between Adaptation and Nostalgia. The Bulgarian Turks in Turkey. Sofia: International Center for Minority Research and Intercultural Relations, 1998, p.140-181.

Anna Krasteva, « Immigration, gender, labor », in : The implication of EU membership on immigration trends and immigrant integration policies for the Bulgarian labor market, Sofia : n.d., 2008, p.101-113.

Anna Krasteva, « Post-communist Discovery of Immigration : The Case of Bulgaria », in : E. Berggren, B. Likic-Brboric, G. Toksoz and N. Trimikliotis (eds), Irregular Labor and Community : A Challenge for Europe, Maastricht : Shaker Publishing, 2007, p.104-117.

Anna Krasteva, « Strengthening Cross-border Cooperation in the Western Balkan Regarding Migration Management - Bulgaria ", in : Migration Flows in Southeastern Europe, a Compendium of National Perspectives, Belgrade : n.d., 2007, p.163-193. 
Anna Krasteva, «L'immigré chinois en Bulgarie. Le "protestant" de l'économie postcommuniste ", in : L. Roulleau-Berger (dir.), Nouvelles migrations chinoises et travail en Europe, Toulouse : Presse Universitaires du Mirail, 2007, p.71-88.

Anna Krasteva and Elena Jileva, «Teaching Ethnicity and Migration in Bulgarian Universities », in : S. Jacobs (ed.), Pedagogies of Teaching « Race » and Ethnicity in Higher Education: British and European Experiences, Birmingham : University of Birmingham, 2006, p.137-159.

Anna Krasteva, « Post-Communist Discovery of Immigration : The Case of Bulgaria », South-East Europe Review for Labour and Social Affairs, 2 2006, p.25-34.

Jana Kubicová and William Bagatelas, « Bulgarian Emigration - A Closer Look », South-East Europe Review for Labour and Social Affairs, 4, 2003, p.27-36.

Detelin Luchev, « Bulgariansfrombanat_worldwide (to the problem of the ethnographic investigation of the communities via internet) », Etnologia Bulgarica, 3, 2006, p.77-92.

Mila Maeva, « New Migration Waves of Bulgarian Turks », in : Elena Marushiakova (ed.), Dynamics of National Identity and Transnational Identities in the Process of European Integration, Cambridge : Cambridge Scholars Publishers, 2007, p.224-247.

Mila Maeva, « The Turks`Image Through Bulgarian Turks` Eyes », Ethnologia Bulgarica, 3, 2006, p. 103-112.

Mila Maeva, « Bulgarian Turks and European Union », In : Horatiu Rusu and Bogdan Voicu (eds.), EU Integration Process from EAST to EAST : Civil Society and Ethnic Minorities in a Changing World. Proceedings from a round table for young social scientists, Sibiu: Psihomedia Publishing House, 2005, p.119-126.

Mila Maeva, « The Revival Process and its influence on Bulgarian Turks' Identity in Turkey », Area studies, 2, 2004, à l'adresse : http://www.sant.ox.ac.uk/areastudies/maeva.pdf

Mila Mancheva, « Migration Trends from Bulgaria to Germany. Migratory Groups and Sociocultural Profiles », in : Anna Krasteva (ed.), Migration in and from Southeastern Europe, Europe\&Balkans Series, Longo Editore: Ravenna (à paraître).

Mila Mancheva, «Emigration and Economic Transition at Home : The Case of Bulgaria », in: Richard Black (ed.), Distant Development : Migrant Diasporas in Collective Transnational Activity, Amsterdam University Press : Amsterdam, 2008 (à paraître).

Mila Mancheva, « Practicing Identities Across Borders. The Case of Bulgarian Turk Irregular Labor Migrants in Germany ", in : P.M. Smith and John Eade (eds.), Comparative Urban and Community Research, vol. 9, New Brunswick : Transaction Publishers, 2008 (à paraître).

Mila Mancheva, «Ethnic Politics under Transition : Ethnic Migration and the Representation of Ethnic Interests - the Case of Bulgaria », in : Ethnic Politics within System Transformation : Ethnic Migration and the Representation of Ethnic Interests in Comparison (Bulgaria, Estonia, Romania, Slovakia), Berlin : Humboldt University, 2004.

Eugenia Markova, Gaining from Migration: The Case of Bulgaria, Paris : OECD Development Centre, 2007.

Eugenia Markova, « The Performance of Bulgarian Undocumented and Legalised Immigrants in the Spanish Labour Market », Sussex Migration Working Paper, 31, 2006.

Eugenia Markova, « Recent Phenomena - Employment Initiatives towards Immigrants in Greece ", in : Jochen Blaschke and Bastian Vollmer (eds.), Employment Strategies for Immigrants in the European Union, Edition Parabolis : Berlin, 2004, p.201-238. 
Eugenia Markova, «A Survey of Bulgarian Immigrants in Greece and Spain », Sofia: Institute for Market Economics (IME), 164, mars 2004, à l'adresse : http://www.ime-bg.org/pr bg

Eugenia Markova and Richard Black, New East European Immigration and Community Cohesion. York Publishing : Joseph Rowntree Foundation, 2007, à l'adresse : http://www.jrf.org.uk/bookshop/ eBooks/2053-immigration-community-cohesion.pdf

Eugenia Markova and Barry Reilly, « The Determinants of Labor Market Earnings for Bulgarian Migrants: Some Micro-Level Evidence from Madrid, Spain », Migration Letters, 5(2), octobre 2008, p.177-188, à l'adresse: http://www.migrationletters.com/200802/

Markova_Reilly_2008_vol5_no2_177_188.pdf

Eugenia Markova and Barry Reilly, «Bulgarian Migrant Remittances and Legal Status : Some Micro-level Evidence from Madrid », South-Eastern Europe Journal of Economics, 5(1), 2007, p.55-71.

Eugenia Markova and Alexander Sarris, « The Decision to Legalize Bulgarian Illegal Immigrants in Greece », in : Slobodan Djajic (ed.), International Migration. Trends, Policies and Economic Impact, London \& New York : Routledge, 2001.

Eugenia Markova and Alexander Sarris, « The Performance of Bulgarian Illegal Migrants in the Greek Labour Market », South European Society \& Politics, 2 (2), 1997, p.57-77.

Elena Marushiakova, Udo Mischek, Vesselin Popov, Bernhard Streck (Hg.), Zigeuner am Schwarzen Meer, Leipzig : Eudora Verlag, 2008.

Elena Marušiakova et Veselin Popov, « De l'Est a l'Ouest. Chronologie et typologie des migrations tsiganes en Europe », Etudes tsiganes, 27-28, 2006, p.10-26.

Elena Marušiakova et Veselin Popov, « La mobilité des Tsiganes dans la fédération des Etats indépendants ", Etudes tsiganes, 27-28, 2006, p.28-43.

Elena Marushiakova, Vesselin Popov and Mirella Decheva, « The Gypsies in Bulgaria and their Migrations ", in : Will Guy, Zdenek Uherek and Renata Weinerova (eds.), Roma Migration in Europe : Case Studies, Münster : Lit, 2004, p.135-142.

Yaron Matras, « Romani Migrations in the Post-Communist Era », Cambridge Review of International Affairs, 13(2), 2000, p.32-50.

Dimitrina Mihaylova, « Between a Rock and a Hard Place : Pomaks Identities at the Border between Bulgaria and Greece », Focal. European Journal of Anthropology, 41, 2003, p.45-57.

Minko Minkov, « La migration internationale en Bulgarie », Revue européenne des migrations Internationales, 10 (2), 1994, p.163-173.

Vesselin Mintchev, «Stay or Leave Again? New Evidence for Bulgarian Return Migration », Ikonomičeska misăl, 7, 2007, p.107-126.

Vesselin Mintchev, « The Profile and Experience of Return Migrants : Empirical Evidence from Bulgaria », South-East Europe Review for Labour and Social Affairs, 2, 2006, p.35-59.

Vesselin Mintchev and Venelin Boshnakov, « Bulgarian Return Migration and Remittances : Alternative Estimates of Worker Remittances Inflow After $2000 »$, Bulgarian Academy of Sciences - Institute of Economics \& University of National and World Economy (UNWE), Sofia, 11 mai 2006, à l'adresse : http://papers.ssrn.com/sol3/cf_dev/AbsByAuth.cfm?per_id=371392

Vesselin Mintchev, Venelin Boshnakov, Jordan Kaltchev, Valentin Goev, « Who is leaving? Potential emigration from Bulgaria in the beginning of the XXI century ", 2003, à l'adresse : http://www.cerge-ei.cz/pdf/gdn/RRCIII_28_paper_01.pdf 
Vesselin Mintchev, «External Migration and External Migration Policies in Bulgaria », South-East Europe Review for Labour and Social Affairs, 3, 1999, p.123-150.

Mirjana Morokvasic, «La mobilité transnationale comme ressource : le cas des migrants de l'Europe de l'Est », Cultures et Conflits, 33-34, printemps-été 1999.

Nacionalen centăr za izsledvane na obštestvenoto menie (NCIOM), « The Expectations of the Bulgarian Citizen about their Social Mobility in the EU after the Accession in 2007. National representative survey ", », Sofia : NSIOM, 2005.

Marina Nikolova, «Greece as a Sophistication of Necessary Reality : Perceptions and Images from the Narratives of Women Immigrants from Bulgaria », South-East Europe Review for Labour and Social Affairs, 3, 2006, p.83-90.

Michel Palairet, « The Migrant Workers of the Balkans and their Villages (18th Century-World War II) », in : Klaus Roth (hg.), Handwerk in Mittel- un Südosteuropa, München: SüdosteuropaGesellschaft, 1987, p.23-46.

Ayse Parla, « Irregular Workers or Ethnic Kin?: Post 1990s Labor Migration from Bulgaria to Turkey », International Migration, 45(3), 2007, p.157-181.

Ayse Parla, « Longing, Belonging and Locations of Homeland among Turkish Immigrants from Bulgaria ", Journal of Southeast European and Black Sea Studies 6(4), 2006, p.543-557.

Ayse Parla, « Marking Time along the Bulgarian-Turkish Border », Ethnography 4(4), 2003, p. 561-575.

Petăr Petrov, « Coping with Strangeness : Adaptive Strategies of "Returnees" ", Ethnologia Bulgarica. Yearbook of Bulgarian Ethnology and Folklore, 2, 2001, p.25-36.

Ekaterina Popova and Marko Hajdinjak (eds.), Forced Ethnic Migrations on the Balkans: consequences and Rebuilding of Societites (Conference Proceedings), Sofia : IMIR, 2006.

Julianna Puskás (ed.), Overseas Migration from East Central and Southeastern Europe : 1880-1940, Budapest : Akadémiai Kiadó, 1990.

Rossitsa Rangelova and Katja Vladimirova, « Migration from Central and Eastern Europe : The Case of Bulgaria », South-East Europe Review for Labour and Social Affairs, 3, 2004, p.7-30.

Radovan Samardzić and Mita Djordjević (eds), Migrations in Balkan History, Belgrade : Srpska akademija nauka i umetnosti, 1989.

Denislava Simeonova, Negative Effects of Securitising Immigration: The Case of Bulgarian Migrants to EU, Prague : Multicultural Centre Prague, 2004, à l'adresse : http://aa.ecn.cz/img_upload/ f76c21488a048c95bc0a5f12deece153/

DSimeonova_Negative_Effects_of_Securitizing_Immigration.pdf

Magdalena Slavkova, Labor Mobility of Bulgarian Roma/Gypsies. Country report. Bourses de recherche pour jeunes chercheurs en sciences humaines et sociales. Maison des sciences de l'homme et de la société de Sofia, Maison des sciences de l'homme (Paris), 2008.

Magdalena Slavkova, «Contemporary labor migrations of Gypsies from Bulgaria to Spain », in : Elena Marushiakova (ed.), Dynamics of National Identity and Transnational Identities in the Process of European Integration, Cambridge : Cambridge Scholars Publishing, 2008, p.189-213.

Magdalena Slavkova, Roma Migrations from Bulgaria to the EU Countries. Country Report to the Lungo Drom project of Intercultural Institute of Timişoara and ASPROSOCU NGO in Spain, 2007. 
Eva Sobotka, « Romani Migration in the 1990s: Perspectives on Dynamics, Interpretation and Policy », Romani Studies, 13(2), 2003, p.79-122, à l'adresse : http://www.marston.co.uk/RSPP/ LUPRSV013P02A00079.pdf

Ralitza Soultanova, Les migrations multiples de la population bulgare, actes du colloque, La France et les migrants des Balkans : un état des lieux, 20 janvier 2005, Paris, Courrier des Balkans, à l'adresse : http://balkans.courriers.info/IMG/rtf/Les_migrations_multiples_de_la_population_bulgare.rtf Ralitza Soultanova, « Le gourbet ou la mobilité réinventé », in : Andrea Rea et Ralitza Soulatnova (dir), Les migrations de l'Est vers l'Ouest : entre mobilités et installation, Bruxelles (à paraître).

Krassen Stanchev (ed.), Bulgarian Migration: Incentives and Constellations, Sofia : Open Society Institute, 2005.

Alice Szczepaniková, Marek Čaněk and Jan Grill (Eds.), Migration Processes in Central and Eastern Europe. Unpacking the Diversity, Prague : Multikulturní centrum Praha/Multicultural Center Prague, 2006, à l'adresse : http://www.migration-boell.de/downloads/integration/ Migration_Processes_in_CEE_MKC.pdf

Albena Tcholakova, « Nouvelles circulations migratoires et figures de réfugiés en Bulgarie », Hommes et migrations, 1266, mars-avril 2007.

Angelina Tchorbadjiyska, « Bulgarian Experiences with Visa Policy in the Accession Process: A Story of Visa Lists, Citizenship and Limitations on Citizens' Rights », Regio, 1, 2007, p.88-105.

Ilona Tomova, « Migration of Roma in Bulgaria », in : Ekaterina Popova and Marko Hajdinjak (eds.), Forced Ethnic Migrations on the Balkans: consequences and Rebuilding of Societites (Conference Proceedings), Sofia : IMIR, 2006, p.124-137.

Stoyan Totev and Jordan Kalchev, « Emigration Processes and the Socio-economic Development in Bulgaria ». Studi emigrazione, 139, septembre 2000.

Stefan Troebst, « Nationalismus vs. Demokratie : Der Fall Bulgarien » [Nationalisme contre démocratie : le cas de la Bulgarie], in : Margareta Mommsen (dir), Nationalismus in Osteuropa. Gefahrvolle Wege in die Demokratie [Le nationalisme en Europe de l'Est. Le chemin plein de danger de la démocratie], Munich : C.H. Beck Verlag, 1992, p.177.

Darina Vassileva, « Bulgarian Turks Emigration and Return », International Migration Review, 26(2), 1992, p.342-352.

Gregory Weeks, Hazel Slinn, Ann Henry, Yoanna Dumanova, « Four accounts on «brain drain» in the Balkans ", South-East Europe Review for Labour and Social Affairs, 4, 2003, p.13-26.

Heinz Werner, « From Guests to Permanent Stayers? From the German « Guestworker » Programmes of the Sixties to the Current « Green Card » Initiative for IT Specialists », IAB Labour Market Research Topics, 43, 2001, à l'adresse : http://eric.ed.gov/ERICDocs/data/ericdocs2sql/ content_storage_01/0000019b/80/19/1c/cc.pdf

Antonina Zhelyazkova, Nadežda Daskalova et al., Trade Unions against Racism and Discrimination, Sofia : IMIR, 2003, dans le cadre du "RITU project on Racial and Ethnic Minorities, Immigration and the role of Trade Unions in Combating Discrimination and Xenophobia, in Encouraging Participation and in Securiting Social Inclusion and Citizenship", à l'adresse : http://www.imirbg.org/imir/books/RITU Bulgarian Best Practice Guide.pdf

Antonina Zhelyazkova (ed.), Between Adaptation and Nostalgia : The Bulgarian Turks in Turkey. Sofia : International Center for Minority Research and Intercultural Relations (IMIR), 1998. 
Antonina Zhelyazkova, « The Social and Cultural Adaptation of Bulgarian Immigrants in Turkey ", in : Antonina Zhelyazkova (ed.), Between Adaptation and Nostalgia : The Bulgarian Turks in Turkey, Sofia : IMIR, 1998, p.11-44.

\section{C - Mémoires universitaires non publiés}

Magdalina Dzhamdzhieva, «Les nouveaux nomades. Les mobilités scientifiques des étudiants bulgares depuis 1989 », Mémoire de DEA romand en sociologie, Université de Neuchâtel, Faculté des sciences économiques et sociales.

Christoph Gille, Romanians and Bulgarians in Male Street Sex Work in German Cities. A comparison between their perceptions of living conditions in the countries of origin and in Germany as an example for a broader European migratory pattern, Master Comparative European Social Studies, Hogeschool Zuyd, Maastricht, Metropolitan University London, 2005, à l'adresse : http://www.correlationnet.org/pdf_highlight/rom_bulg_male_sex_work.pdf

Magdaléna Hadjiisky, Les migrations est-européennes dans le contexte de la transition : l'exemple de l'émigration bulgare, DEA d'études soviétiques et est-européennes, Paris : Sciences Po, 1993.

Vassil Nikolov, Taming Emigration: Bulgaria and Other Selected Cases, MA Thesis, Nationalism Studies Program, Central European University, Budapest, 2005, à l'adresse : http://www.personal.ceu.hu/ students/04/Vassil_Nikolov/Thesis.pdf

Ayşe Parla, Terms of Belonging: Turkish Immigrants from Bulgaria in the Imagined Homeland, Dissertation Thesis, New York University : Department of Anthropology, 2005.

\section{D - Rapports d'organisations internationales et d'instances étatiques}

Iskra Beleva and Mariana Kotzeva, Skilled Labour Migration from Developing Countries: Study on Bulgaria. Geneva : International Labour Office (ILO), 2001.

Daniela Bobeva and Jordan Kalchev, Transit Migration in Bulgaria, Budapest : IOM-Budapest, 1994.

Micheál Ó Cinnéide and Eugenia Markova, Population Dynamics, Governance and Local Development in a Transition Economy: The Case of Bulgaria, Paris : OECD, 2005.

European Commission, DG JHA, Country Report Bulgaria 2003 on Asylum and Migration, à l'adresse : http://ec.europa.eu/justice_home/doc_centre/asylum/statistics/docs/2003/country_reports/ bulgaria.pdf

European Commission, Migration - Europe's Integration and the Labour Force Brain Drain from Central and Eastern Europe, Brussels : European Commission, COST, 1997.

Eurostat, « Données en bref, Premières estimations démographiques pour 2007 », Population et conditions sociales, 3, 2008, p.1, à l'adresse : http://epp.eurostat.ec.europa.eu/cache/ ITY_OFFPUB/KS-QA-08-003/FR/KS-QA-08-003-FR.PDF

August Gächter \& International Labour Office (ILO), « The Ambiguities of Emigration : Bulgaria since 1988 », International Migration Papers, 39, 2002, Geneva, à l'adresse : http://www.ilo.org/ public/english/protection/migrant/download/imp/imp39.pdf

Rossitza Guentcheva, Petya Kabakchieva and Plamen Kolarski, « Bulgaria : The Social Impact of Seasonal Migration », in : Sharing Experience : Migration Trends in Selected Applicant Countries and 
Lessons Learned from the 'New Countries of Immigration' in the EU and Austria, Vol I. Vienna : International Organization for Migration (IOM), 2003, à l'adresse : http://www.iom.int/ DOCUMENTS/PUBLICATION/EN/IOM_I_BG.pdf

House of Commons. Trade and Industry Committee. Europe moves East : The Impact of the new EU Member states on UK business. Eleventh Report of Session 2006-2007, London: House of Commons, 18 october 2007 (esp. chap. 2 on « Migration»).

International Organization for Migration (IOM)-Sofia, Migration Potential in Bulgaria, Sofia : IOM, 2001.

International Organization for Migration (IOM) Technical Cooperation Centre for Europe and Central Asia, « Migration Potential in Central and Eastern Europe », Geneva : IOM, 1999, à l'adresse : http://iom.ramdisk.net/iom/images/uploads/IOM TCC Rep_1071067863.pdf Jordan Kalchev, Profile and motives of potential migrants from Bulgaria, Geneva : IOM, 1997. Nacionalen statističeski institut (NSI), Vătrešna i vănšna migracija na naselenieto na kraija na 1990-te godini, Sofia : NSI, 1992.

Nacionalna strategija za demografsko razvitie na Republika Bălgarija, 2006-2020 [Stratégie nationale pour le développement démographique de la République de Bulgarie, 2006-2020], Sofia : Ministerstvo na truda i socialna politika, 2007, à l'adresse : http://www.mlsp.government.bg/bg/ docs/demography/STRATEGY- FINAL.pdf

Organisation for Economic Co-operation and Development (OECD), Migration Policies and EU Enlargement. The Case of Central and Eastern Europe, Paris: OECD, 2001, à l'adresse : http:// books.google.com/books? $\mathrm{hl}=$ en\&id=SMKKzuCqmtQC\&dq=Migration+Policies+and+EU+Enlargement. +The+Case+of+Central+and+Eastern+Europe\&printsec=frontcover\&source=web\&ots=hUzUlvaL0D\&sig=GZ9Wp8Xdv7ISf8AljvVmahPcgI\&sa=X\&oi=book_result\&resnum=1\&ct=resu

Alain Reyniers, Evaluation of Gypsy Populations and their Movements in Centr 